\title{
The Productivity Gap: Monetary Policy, the Subprime Boom, and the Post-2001 Productivity Surge
}

\author{
George Selgin \\ Senior Fellow and Director \\ Center for Monetary and Financial Alternatives \\ Cato Institute \\ 1000 Massachusetts Ave, NW \\ Washington, DC 2001 \\ gselgin@ cato.org \\ David Beckworth \\ Associate Professor of Economics \\ Western Kentucky University \\ 1906 Colelge Heights Boulevard \#11059 \\ Bowling Green, KY 42101 \\ david.beckworth@wku.edu \\ Berrak Bahadir \\ Assistant Professor of Economics \\ Özyeğin University \\ Çekmeköy Campus \\ berrak.bahadir@ozyegin.edu.tr
}

February 2015

\begin{abstract}
It is widely believed that, in the wake of the dot.com crash, the Fed kept the federal funds target rate too low for too long, inadvertently contributing to the subprime boom. We attribute this and other Fed departures from a "neutral" policy stance to the Fed's failure to respond appropriately to exceptional rates of total factor productivity growth. We then show how the Fed, by adhering to a nominal GDP growth rate target, might have succeeded in maintaining such a neutral stance.
\end{abstract}

JEL Classification: E32, E52

Keywords: Productivity, neutral interest rate, output gap, business cycle 


\section{Introduction}

Several authorities (e.g. Ahrend, Cournède and Price 2008; Taylor 2009; Iacoviello and Neri 2011) have argued that the housing boom of 2002-2007 was encouraged by the Fed's monetary policy stance in the wake of the 2001 dot.com crash. That stance involved setting the federal funds rate target at levels that proved, in retrospect, too low. According to this view, the boom would have been less pronounced, and the consequent bust less severe, had the Fed's stance been less accommodative.

Such claims raise the question, what caused the FOMC to select a path for the federal funds rate that appears to have contributed to a housing-market bubble? What caused it to conclude that, in setting its targets as it did, it was merely helping to achieve a "soft landing" from the 2001 crash, and not setting the stage for a further and ultimately more serious round of boom and bust? Might the cause, whatever it was, also have played a part in past cycles?

We trace the Fed's unintentional contribution to the business cycle to its failure to respond appropriately to persistent changes in the growth rate of total factor productivity. In particular, we argue that, when that growth rate surged following the dot.com crash, the Fed responded, not by adjusting its federal funds rate upwards as theory suggests it ought to have done, but by treating the surge as allowing it to maintain an exceptionally low federal funds rate without risking the rise in inflation that such a low rate would otherwise have entailed. Finally, we show that the Fed might have maintained an approximately neutral stance by adhering to a nominal GDP growth rate rule.

\section{Monetary Policy and Productivity}

Monetary policy in the U.S. has long been based on targeting the federal funds rate. Responsibility for setting the target falls on the FOMC. One way of understanding the challenge facing the FOMC, originating with Wicksell, is as that of achieving a " neutral" monetary policy stance, meaning one that minimizes the Fed's contribution to either booms or busts (Bernhardsen and Gerdrup 2007), where the funds rate consistent with such a stance is the "neutral" or "natural" rate of interest.

Were the real neutral federal funds rate directly observable, implementing a neutral monetary policy would be simple. But because that rate is neither observable nor readily estimated, the Fed instead adjusts its target in response to other, directly observable variables, including the rates of inflation and unemployment, changes in which at best supply only a rough indication of discrepancies between targeted and natural interest rates.

Although the neutral federal funds rate isn't observable, the basic determinants of that rate are uncontroversial, being implied by many standard economic models. Consider for example a simple growth model in which a representative household's lifetime utility is given by

$$
\max E_{0} \sum_{t=o}^{\infty}(\beta)^{t} \frac{\left(C_{t} / N_{t}\right)^{1-\sigma}}{1-\sigma}
$$

where $0<\beta<1$ is the household's discount factor and $\sigma$ is a risk aversion parameter. 
The economy's periodic flow of funds is given by

$$
K_{t+1}=Y_{t}-C_{t}+(1-\delta) K_{t}
$$

where $K$ is capital and $\delta$ is the rate of depreciation. Annual production, $Y_{t}$, is given by

$$
Y_{t}=A_{t} K_{t}^{\mu} N_{t}^{(1-\mu)} \text {, }
$$

where $N_{t}$ is labor input, which grows at rate $\mathrm{n}$, and $A_{t}$ is technological progress, which grows at rate $g$.

Dividing (2) by efficiency-weighted labor input $(A N)$, while letting $k=K / A N, c=C / A N$, and $y=Y / A N=k^{\mu}$, yields

$$
k_{t+1}=\frac{1}{(1+n)(1+g)}\left[k_{t}^{\mu}-c_{t}+(1-\delta) k_{t}\right] .
$$

The optimization problem can then be rewritten

$$
\max E_{0} \sum_{t=o}^{\infty}\left(\beta(1+g)^{(1-\sigma)}\right)^{\prime} \frac{c_{t}^{1-\sigma}}{1-\sigma} .
$$

Maximizing (4) subject to (3) yields the first order conditions

$$
\begin{aligned}
c_{t}: & c_{t}^{-\sigma}=\frac{1}{(1+n)(1+g)} \lambda_{t} ; \text { and } \\
k_{t+1} \quad: \quad & \lambda_{t}=\beta(1+g)^{(1-\sigma)}\left(\mu k_{t+1}^{(\mu-1)}+(1-\delta)\right) \frac{1}{(1+n)(1+g)} \lambda_{t+1} .
\end{aligned}
$$

If the market for inputs is perfectly competitive, profit maximization requires that the real return to capital equal its marginal product plus one minus the rate of depreciation

$$
R_{t}=\mu k_{t+1}^{(\mu-1)}+(1-\delta)
$$

Solving the first order conditions for $c_{t}=c_{t+1}$ yields the steady state real (net) neutral rate of interest:

$$
\bar{r}^{n}=\bar{R}^{n}-1=-\ln (\beta)+\sigma g+n
$$

The real neutral rate is thus a log-linear function of the discount (time preference) rate, productivity growth, and labor input growth.

Of these fundamental determinants of the neutral rate, the productivity growth rate is the one to which substantial recent movements in the U.S. neutral rate of interest are most readily attributed. As Figure 1 shows, between 1970 and 2006 the total factor productivity (TFP) growth ranged from as high as 5.6 percent to as low as -4.2 percent, with many relatively sharp swings (Fernald, 2009). The most recent of these swings, the productivity "surge" that began in the mid-1990s, was interrupted by the dot.com crash, after which it resumed with greater vigor until 2004. ${ }^{1,2}$ The U.S. population growth rate, in contrast, has been relatively stable since 1970 , seldom

${ }^{1}$ Gordon (2010) attributes the productivity "explosion" of 2001-2004 to a lagged effect of the information and communication technology boom of the late 1990s as well as aggressive cost cutting measures made by firms. Oliner, Sichel, and Stiroh (2007) make a similar argument.

${ }^{2}$ In this figure and in the ones that follow we use the regular TFP measure, not the utilization-adjusted one. We do this since any change in the TFP growth rate-whether it 
varying by more than 28 basis points from a mean of 1 percent. The contribution of changes to the rate of time preference, finally, is also likely to be small, and is in any event highly uncertain. Most macroeconomic models take a constant time preference rate for granted, while recent "evolutionary" models of time preference point to discount rates that largely reflect the sum of population growth and mortality rates, with aggregate uncertainty perhaps constituting an additional (and more variable) source of "present bias" (Robson and Samuelson 2009). Empirical work devoted to measuring discount rates has, on the other hand, "failed to establish any stable estimate," instead yielding a "spectacular" variety of results (Frederick, Loewenstein, and O’Donogue 2002, p. 377).

In light of these considerations, the real neutral rate of interest may be assumed to be roughly equal the sum of the mean neutral rate and fluctuations in the expected growth rate of productivity around its mean, $r_{t}^{n} \cong \bar{r}^{n}+\sigma \hat{g}_{t}$, where $\hat{g}_{t}=g_{t}^{e}-\bar{g}$ and $\bar{g}$ is the mean rate of productivity growth, and achieving a neutral monetary policy stance might be said to depend to a substantial degree on the Fed's adjusting its federal funds target in response to expected changes in the rate of productivity growth. ${ }^{3}$

\subsection{The Productivity Gap and the Output Gap}

With these observations concerning the real neutral rate of interest in mind, we now proceed to contrast the Fed's actual conduct with that required for the achievement of a roughly neutral policy stance. Figure 2 shows a smoothed version of our productivity-based proxy for the real neutral federal funds rate together with the actual real federal funds rate for the period 1970:Q1 2006:Q4. ${ }^{4}$ Departures from neutral monetary policy are represented here by the spread $r_{t}^{A}-$ $\left(\bar{r}^{n}+\sigma \hat{g}_{t}\right)$, where $r_{t}^{A}$ is the actual real federal funds rate and $\bar{r}^{n}+\sigma \hat{g}_{t}$ is the neutral rate proxy. Because the proxy assumes that the neutral rate only varies with changes in the growth rate of productivity, we refer to this spread as the "Productivity Gap." A positive Productivity Gap means that the target real federal funds rate is above the assumed real neutral rate, so that monetary policy is too tight, whereas a negative Productivity Gap means that monetary policy is too easy. Figure 3 plots the Productivity Gap since 1970.

The direction and magnitude of monetary policy errors implied by the Productivity Gap agree at least roughly with conventional wisdom. Fed policy was, according to our measure, excessively easy during the 1970s (though less so in the immediate wake of the first oil supply shock) and excessively tight during Volcker's anti-inflation campaign. In the nineties policy was at first easy and then somewhat (though not dramatically) tight. At the time of the tech bubble crash, monetary policy appears to have been more-or-less neutral. Starting in 2002, however, it became increasingly easy, with the Productivity Gap reaching its lowest value in the sample period at the height of the housing boom.

comes from technology innovations or better utilization of factor inputs-will affect the neutral interest rate. It is, therefore, important to track the overall TFP measure when considering how monetary policy should respond to changes in the neutral interest rate.

${ }^{3}$ That such productivity-based adjustments to the federal funds target are consistent with optimal stabilization policy in the presence of price-setting frictions has been formally demonstrated in several recent studies (e.g. Tambalotti 2003; Edge, Laubach, and Williams 2005; Christiano, Motto, and Rostagno 2007; and Sims 2012).

${ }^{4}$ The real federal funds rate is constructed by subtracting the year-on-year inflation rate from the federal funds rate. 
The Productivity Gap's merit as a rough indicator of the non-neutrality of monetary policy is further suggested by the degree to which it correlates with other such indicators, including estimates of the " output gap" and of housing market activity. The output gap is the difference between actual and natural output. As Berhardsen and Gerdrup (2007, p. 54) and Williams (2003, p. 1) observe, a neutral rate of interest can be understood as one that "closes" the output gap. The output gap will be positive if the policy rate is below its natural level, and negative when the rate is above that level.

Following Woodford (2003, p. 246), one may formally define the relationship between the output gap and interest rate gap as follows

$$
\hat{y}_{t}=E_{t} \hat{y}_{t+1}-\frac{1}{\sigma}\left(r_{t}^{A}-r_{t}^{n}\right)
$$

where the output gap, $\hat{y}_{t}$ is the percentage deviation of real GDP from its natural level. Solving Equation 7 recursively forward yields

$$
\hat{y}_{t}=-\frac{1}{\sigma} \sum_{i=0}^{\infty}\left(r_{t+i}^{A}-r_{t+i}^{n}\right)
$$

The relationship between the output and productivity gaps is then given by

$$
\hat{y}_{t}=-\frac{1}{\sigma} \sum_{i=0}^{\infty}\left(r_{t+i}^{A}-\bar{r}^{n}-\sigma \hat{g}_{t+i}\right)
$$

If fluctuations in the neutral interest rate do indeed reflect deviations of the productivity growth rate from its long-run trend, the Productivity Gap should be negatively correlated with the output gap, because a positive Productivity Gap means that monetary policy is excessively tight. That this has in fact been the case is suggested by Figure 4, which plots the negative of the Productivity Gap along with the output gap lagged 5 quarters. ${ }^{5}$ The series have $R^{2}$ of 0.65 .

Because a gap between the neutral and actual rates of interest implies a difference between the rate at which funds can be borrowed and either the marginal product of capital or households' discount rates, a negative gap will encourage borrowing, while a positive one will discourage it. Consequently, if the Productivity Gap approximates the actual neutral rate gap, the demand for durable assets, including housing, should be negatively correlated with it. One measure of such demand, of particular interest in light of recent events, is the number of housing starts. Figure 5 plots the Productivity Gap and lagged housing starts. Here again the series are indeed correlated, with $R^{2}=0.38$.

\subsection{The Productivity Gap and the Taylor Gap}

Instead of adjusting its federal funds target in direct response to either observed or anticipated deviations of productivity growth from trend, the Fed responds mainly to observed and forecasted values of unemployment and inflation. This tendency can be seen in Figure 6, which shows the average cumulative responses of total factor productivity (TFP), the federal funds rate, the inflation rate, the unemployment rate, and the output gap to a one standard deviation positive shock to the TFP growth rate for the period 1970:Q1-2006:Q4. ${ }^{6}$

${ }^{5}$ We use the Laubach and Williams's (2003) output gap measure rather than the CBO's output gap because the latter assumes that the growth rate of output does not vary much in the short-run. See Weidener and Williams (2009) for further discussion.

${ }^{6}$ The responses are derived from a vector autoregression (VAR). The VAR uses 6 lags to eliminate serial correlation and identifies the TFP shock using long-run restrictions. The 
According to these estimates, a positive TFP shock during the sample period led to a reduced inflation rate and to a modestly increased rate of unemployment, to which the Fed tended to respond by reducing the federal funds rate, as if seeking to limit the inflation and unemployment rate changes. This response is however opposite that called for according to our neutral rate proxy if policy is to remain neutral. Consequently, the response gives rise to a positive output gap.

The Fed's conduct as depicted in Figure 6 appears consistent here with its "dual mandate," which makes the Fed responsible for combating unemployment and stabilizing inflation, but not for maintaining a neutral policy stance as such.

The dual mandate is also reflected in the Taylor Rule, according to which

$$
i_{t}^{*}=\pi_{t}+\bar{r}^{n}+0.5\left(\pi_{t}-\pi^{*}\right)+0.5\left(y_{t}-y_{t}^{P}\right)
$$

where $i^{*}$ is the nominal federal funds target, $\pi$ is the inflation rate over the last year, $\pi^{*}$ is the inflation target, $y$ and $y^{P}$ are the observed and potential of log real output, respectively. Here the FOMC assigns equal importance to the output gap (itself a proxy for future inflation) and the gap between actual and originally desired inflation rates.

Because it appeared to describe the Fed's conduct during an interval of exceptional macroeconomic stability - the first part of the "Great Moderation"-the Taylor Rule came to be regarded as offering a rough-and-ready guide to optimal monetary policy. Deviations of the Fed's target federal funds rate from that implied by the Taylor Rule therefore supply an alternative measure of the extent to which monetary policy has been either too easy or too tight. Taylor himself claims that the Fed departed substantially from the Taylor Rule during the recent housing boom (Taylor 2009).

Because the difference between the actual funds rate and its Taylor Rule value-henceforth "The Taylor Gap" - and the Productivity Gap are both supposed to indicate the stance of monetary policy, it is worth considering the extent to which the two measures coincide. That the coincidence is in fact substantial is shown by Figure 7. The $R^{2}$ for the two gaps is an impressive 0.80 .

That the Taylor and Productivity Gaps move together is not surprising in light of the previously observed, negative correlation between the Productivity Gap and the output gap, the latter of which forms one of the Taylor Rule's two indicators of the relative easiness of monetary policy. The coincidence of the gaps suggests that changes in the neutral funds rate and in the output gap are both driven to a substantial degree by changes in the economy's rate of productivity growth. It suggests as well that the Taylor Rule, with its output gap component, provides reasonably well for needed adjustments to such changes. Because changes in the Productivity Gap occur relatively early in the business cycle, however, a policy aimed at minimizing the Productivity Gap calls for an earlier response to the turn of the cycle than that called for by the Taylor Rule.

long-run restriction are imposed such that only innovations to TFP can permanently influence the level of TFP. While these restrictions impose long-run structure on the data, they do not in any way constrain the short-run dynamics of the data. Thus, we are letting the data "speak for itself" in the short run. Since the other series are all in growth rate form, we first-difference the $\log$ of the TFP. The other series are also first differenced to induce stationarity. The impulse response functions are accumulated to create responses seen in figure 6 . This approach occurs in the literature on technology shocks that begins with Gali (1999) and has been found to be robust by Whelan (2009). The dashed lines in the figure are standard error bands calculated using standard Monte Carlo techniques. The appendix gives data sources. 
This last point can be illustrated by comparing Taylor's (2007) estimate of how the federal funds rate would have evolved after 2001, had his rule been strictly followed, with a similar estimate of how the rate would have evolved had the target been based on our own neutral rate proxy. The two counterfactual federal funds series are shown, together with the actual rate, in Figure 8. Figure 9 in turn shows actual and simulated counterfactual housing starts for these alternative federal funds rate series. ${ }^{7}$

\section{The Productivity Surge and the Subprime Boom}

Our Taylor Gap and Productivity Gap measures both suggest that monetary policy was excessively easy in the aftermath of the dot.com collapse, and that it was so to an extent unmatched since the 1970s. The Productivity Gap measure points, furthermore, to the more specific conclusion that the Fed erred by failing to raise its target rate in response to renewed productivity growth following the dot.com crash.

A comparison of the Fed's response during the first (pre-dot.com crash) and second (post-crash) phases of the recent productivity surge is revealing. Before the crash, the Fed raised its target rate aggressively, keeping the federal funds rate either at or somewhat above both its Taylor Rule level and our own crude neutral rate proxy. As the productivity surge continued, however, Fed policy became increasingly more accommodative. Finally, in the wake of the dot.com crash, the Fed, instead of responding to renewed productivity growth by correspondingly raising its target, responded perversely, lowering the real funds rate until it actually became negative.

Anecdotal evidence suggests that the Fed's conduct was informed by two interacting factors. First, as Richard Anderson and Kevin Kleisen (2010) explain, the Fed only gradually came to appreciate the magnitude and enduring nature of the post-2000 revival and acceleration of productivity growth. Second, as it did so, it also came to modify its position concerning the bearing of persistent productivity growth on appropriate adjustments of the federal funds rate target. Alan Greenspan (2004) explained the nature of the change in his January 2004 speech at the AEA meetings:

As a consequence of the improving trend in structural productivity growth that was apparent from 1995 forward, we at the Fed were able to be much more accommodative to the rise in economic growth than our past experiences would have deemed prudent. We were motivated, in part, by the view that the evident structural economic changes rendered suspect, at best, the prevailing notion in the early 1990s of an elevated and reasonably stable NAIRU (non-accelerating inflation rate of unemployment). Those views were reinforced as inflation continued to fall in the context of a declining unemployment rate that by 2000 had dipped below 4 percent in the United States for the first time in three decades.

In short, after 2000 the FOMC became especially inclined to overlook the bearing of accelerating productivity growth on the real neutral rate of interest, instead emphasizing its bearing upon the likely course of inflation. Because more rapid productivity growth reduced the likelihood

${ }^{7}$ Figure 8 uses the smoothed federal funds rate paths implied by the Taylor-rule and the neutral federal funds rate. The rates are smoothed by 25 basis point increments so as to mimic the Fed's policy of smoothly adjusting the policy rate. Figure 9 plots the counterfactual simulation using the baseline model in Taylor (2007) where a lag of federal funds rate is regressed on housing starts. 
of inflation, while raising that of disinflation, the FOMC concluded that the Fed could afford to play a more aggressive part in combatting the dot.com recession.

In contrast, while the dot.com boom was still underway, the FOMC regarded accelerating productivity growth as calling for rate increases to dampen the boom. During its February 2000 meeting, for example, in response to both unexpectedly high staff productivity growth estimates and concerns that still more robust growth might be in the offing, Fed Governor Meyer opined:

[I]f the acceleration in productivity leads to continued expectations of accelerating earnings per share, the only way to eliminate the wealth effect, which has to be eliminated, is for the market rate used by investors to calculate the present value of expected earnings to rise (ibid., p. 146).

Although Meyer worried that overly sharp rate increases might "crack the market," he nevertheless proposed a hike of 25 basis points, to which other committee members agreed. ${ }^{8}$ In subsequent meetings preceding the downturn the committee took a similar stand, raising the target funds rate further, with the aim of limiting profit inflation, in response to additional staff reports of surging productivity growth. After the crash, in contrast, as productivity once again began growing at increasingly high rates, the FOMC no longer concerned itself with the possibility that a failure to raise the funds rate would place it below its neutral level, inflating both anticipated profits and asset prices. Instead, it concerned itself with the potential disinflationary consequences of strong productivity growth, which it sought to counter by leaving its lowered target unchanged.

Some FOMC members acknowledged a shift in the Fed's policy stance. During the January 2003 meeting, for example, Glenn Rudebusch (FOMC January 28-29 2003, p. 28) observed how, beginning in 2002, monetary policy seemed to be guided by "something other than strict Taylor Rule determinants," perhaps owing to the "collapse of the tech bubble in stock prices or to geopolitical risks." At that time the real federal funds rate had been negative for some months, while the Federal Reserve Board's estimates of past and projected annual total factor productivity growth rates were high and rising, with the rate for 2002 placed at $2 \frac{1}{4}$ percent, and that anticipated for both 2003 and 2004 placed at $2 \frac{1}{2}$ percent. Informed by these figures, the FOMC raised its estimate of the permanent component of the multifactor productivity growth rate to $1 \frac{1}{2}$ percent (ibid., p. 74).

Such heightened productivity growth might, as we have seen, have suggested a similarly heightened real neutral federal funds rate, and thus (for any given mean inflation target) the need for a correspondingly increased nominal federal funds rate target. The FOMC nevertheless held the rate at its low post-bust level. This decision appears to have reflected the committee's understanding that, because such an accommodative stance would merely counter the decline in inflation that would otherwise result from exceptionally rapid productivity growth, the stance was not excessively easy. Rapid productivity growth, in other words, was treated as offering the Fed a sort of "free lunch," whereby interest rates might be held below their neutral levels without destabilizing real activity. Indeed, low rates were seen as averting productivity driven deflation.

By March 2003, the Fed's stance was beginning to give rise to high earnings and profits generally, and to a buoyant housing market in particular. Dallas Fed President Bob McTeer (March

${ }^{8}$ To be sure, Governor Meyer was not suggesting that rates ought to be raised simply because the growth rate of productivity had risen. Instead his reasoning was that an increase in permanent income would otherwise lead to excessive borrowing to consequent "overheating" of the economy. (We thank William White for this observation.) 
18, pp. 54-5) reported hearing from one Texas authority that low mortgage rates were serving as "nicotine to the housing industry" and that "mortgage rates could rise by a percentage point or so, maybe even 2 points, from the current very low levels without having a strongly negative effect on housing demand"-an observation consistent with neutral rates having been at least that much higher than those actually prevailing.

Still, the FOMC remained committed to avoiding a decline in "headline" (CPI) inflation. It did so, moreover, despite its awareness that such a policy might not be consistent with keeping interest rates at their neutral levels. During the December 9th FOMC meeting, for instance, Federal Reserve economist David Stockton expressed the Board's belief that the Fed could keep the funds rate "below equilibrium levels" until late 2006 "and still not generate any acceleration of inflation," thereby responding affirmatively to Kansas City Fed President Thomas Hoenig's query as to whether the Board intended to encourage the FOMC to boost output first "and then worry about how far below equilibrium the short-term rate is" (FRB December 2009, pp. 21-2).

Stockton elaborated:

[S] uppose at the end of 2005 the nominal funds rate is 2 percent and you thought that a 4 percent nominal funds rate-a 3 percent real funds rate and 1 percent inflation-was where the rate had to go. Could this Committee raise the funds rate 200 basis point in 2006? I think you certainly could...given what you've demonstrated in the past as a reasonable willingness to be aggressive (ibid., p. 22).

At this time the FOMC was aware of emerging symptoms of an overly-easy policy stance, including a weakening dollar and continued house price inflation. But it appears to have set such considerations aside in favor of an exclusive focus on "balancing" the risks of inflation and deflation. Although President McTeer's view was somewhat more cautious than that of some of his fellow committee members, in other respects it was typical:

I am willing to concede that rapid growth sustained by substantially negative real interest rates may prove a problem. But that problem is not imminent given the degree of productivity growth and slack in the economy .... I believe that the outlook for growth in real GDP is either balanced or biased toward more growth, and I think the outlook for inflation is now balanced.

President McTeer did not appear to allow that exceptionally high productivity growth, instead of justifying negative real interest rates, meant that such rates were especially likely to imply an excessively easy monetary policy stance.

Some months later, Federal Reserve Board Vice Chairman Roger Ferguson, in the course of an October 2004 talk at the University of Connecticut School of Business on the subject of the " equilibrium" (that is neutral) real federal funds rate, observed that the real federal funds rate had recently moved "into positive territory for the first time in three years" (Ferguson 2004, p. 2). Ferguson then went on to observe that rapid productivity growth was "a powerful force tending to make the equilibrium real rate higher than it would otherwise be," while noting how Laubach and Williams' (2003) estimate of the real neutral rate placed it at 3 percent as of mid-2002, a value close to with our own crude estimate. Yet instead of concluding that the Fed's policy stance had been excessively easy, Ferguson defended that stance by citing conditions supposedly warranting departures from a neutral policy. In other words, Ferguson treated a neutral funds rate it as one of several desirable policy objectives that might profitably be traded against one another. 


\section{The Subprime Boom and Inflation Targeting}

The FOMC's decision to forego a neutral "equilibrium" policy stance in favor of one merely geared to "balancing" the risks of inflation and deflation can be understood as involving a tacit switch, in the wake of the tech bubble collapse, from a policy roughly in accord with the Taylor Rule to one that might be characterized as "naive" inflation targeting. This can be seen by estimating a version of the Taylor rule allowing for time-varying output gap and inflation coefficients:

$$
i_{t}^{*}=\pi_{t}+\bar{r}^{n}+\lambda_{1, t}\left(\pi_{t}-\pi^{*}\right)+\lambda_{2, t}\left(y_{t}-y_{t}^{P}\right) .
$$

To allow for interest smoothing we let $i_{i}=\left(1-\rho_{t}\right) i_{t}^{*}+\rho_{t} i_{t-1}$, where $i_{t}$ is the observed federal funds rate. Substituting $i_{t}$ into Equation (11) and defining the neutral nominal federal funds rate as $i_{t}^{n}=\pi_{t}+\bar{r}^{n}$ gives

$$
i_{t}=\left(1-\rho_{t}\right)\left[i_{t}^{n}+\lambda_{1, t}\left(\pi_{t}-\pi^{*}\right)+\lambda_{2, t}\left(y_{t}-y_{t}^{P}\right)\right]+\rho_{t} i_{t-1}
$$

Figure 10 plots values of $\lambda_{1, t}$ and $\lambda_{2, t}$ estimated recursively using a window width of 60 . The figure shows a marked increase in response to inflation following the dot.com bubble crash.

The Fed's shift toward "naive" inflation targeting, informed as it was by the post-2001 productivity surge, was problematic because the rate of inflation consistent with a neutral policy stance varies along with growth rate of productivity, with higher than average productivity growth entailing a lower neutral inflation rate. ${ }^{9}$ The more rapidly productivity grows, the more rapidly unit costs decline. Consequently, the difference between output and input (i.e. wage) inflation rates must also decline. To prevent a productivity based decline in the rate of output price inflation, monetary policy must raise the rate of input price inflation. If input prices are relatively sticky, such a accommodative stance can temporarily swell both current and anticipated profits. In other words, by preventing unusually rapid productivity growth from reducing the rate of inflation, the Fed risked contributing to asset-price inflation no less than it might have if, at a time of average productivity growth, it set its target at level that caused headline inflation to rise. ${ }^{10}$

9 This argument is made informally by Selgin (1997) and formally, using a variety of assumptions, by Tambalotti (2003), Christiano, Motto, and Rastagno (2007), Edge, Laubach and Williams (2007), Schmitt-Grohé and Uribe (2007), and Entekhabi (2008). According to Tambalotti (2003, pp. 30-31), "strict inflation targeting is a particularly undesirable policy to insulate the economy from the effect of trend productivity shocks" because such a policy must involve what is in fact an expansionary stance that "will then result in a boom in demand." Tambalotti finds that, so long as wage rates are more "sticky" than prices of final goods, "a policy that stabilizes nominal wage inflation around its steady state growth rate... would produce better outcomes than those obtained under inflation stabilization" and that "actual policy in the 1990s was very close to optimal" (ibid., p. 32).

${ }^{10}$ According to Christiano, Motto, and Rostagno (2007, p. 18), monetary policy might have been excessively easy during the productivity surge even if the Fed had adhered to the Taylor rule. "In the equilibrium with the Taylor rule," they observe, "the real wage falls, while efficiency dictates that it rise. In effect, in the Taylor rule equilibrium the markets receive a signal that the cost of labor is low, and this is part of the reason that the economy expands so strongly. The 'correct' signal would be sent by a high real wage, and this could be accomplished by allowing the price level to fall. However, in the monetary policy regime 
Nor would having allowed the inflation rate to decline in response to the productivity surge have increased the risk of equilibrium interest rates reaching their zero lower bound, thereby undermining the effectiveness of monetary policy, because, as we have seen, a productivity surge itself entails an increase in real interest rates. ${ }^{11}$

\section{A Nominal GDP Proposal}

Our appraisal of Federal Reserve policy in the years surrounding the crisis suggests that, by treating a productivity surge as justifying further easing, rather than as warranting a corresponding reduction in the rate of inflation, the Fed was led to pursue an excessively easy monetary policy that contributed to rising asset prices.

As noted earlier, a conventional Taylor rule accomplishes this objective to some extent, because both the neutral interest rate and potential real GDP are positively related to an economy's total factor productivity growth rate. However, the Taylor Rule also calls for monetary easing whenever inflation declines below a fixed target value, and does so even when the decline is due to more rapid productivity growth. As Christiano, Motto, and Rostagno (2007) demonstrate, such a Taylor-rule consistent response is also procyclical. ${ }^{12}$

A better rule would have deviations of the productivity growth rate from its long-run trend lead to opposite movements in the Fed's inflation-rate target from its long-run target value, while otherwise still serving to accommodate changes in real money demand. A nominal GDP rule meets this requirement: such a rule stabilizes the growth of total dollar spending, but does not call for any Fed response to short-run changes in the shares of nominal GDP growth represented by real GDP growth on one hand and inflation on the other. ${ }^{13}$

Formally, our suggested nominal GDP rule can be regarded as a special version of the standard Taylor Rule

$$
i_{t}^{*}=i_{t}^{n}+\lambda_{1}\left(\pi_{t}-\pi^{*}\right)+\lambda_{2}\left(y_{t}-y_{t}^{P}\right)
$$

where $i_{t}^{n}$ is the neutral nominal rate and the other variables are as before. Setting $\lambda_{1}=\lambda_{2}=1$ and first differencing $y_{t}$ and $y_{t}^{P}$ gives

$$
i_{t}^{*}=i_{t}^{n}+\left(\Delta y_{t}+\pi_{t}\right)-\left(\Delta y_{t}^{P}+\pi^{*}\right)
$$

governed by our Taylor rule this fall in the price level is not permitted to occur: any threatened fall in the price level is met by a proactive expansion in monetary policy."

${ }^{11}$ Ben Bernanke himself acknowledged this point in correspondence with one of us at the height of the post-2001 productivity surge. "Because supply-induced deflation tends to raise real interest rates, the zero lower bound on rates is generally less relevant in that case, hence the problems for monetary policy created by demand-induced deflation are less likely to arise" (Ben Bernanke to David Beckworth, July 14, 2004). Bernanke added, however, that "While there were some supply factors in the U.S. deflation scare last summer [2003], I note that the economy was below potential at the same time that the funds rate approached zero. So I think concerns about the risks to monetary policy, however remote, were justified in that instance."

12 See footnote 10 for more on this point.

13 While a nominal GDP target remains agnostic about how nominal spending affects real GDP growth and inflation in the short run, it is important to note it does provide a long-run nominal anchor. 
where $\left(\Delta y_{t}+\pi_{t}\right)$ is approximately equal to growth rate of nominal GDP. Defining the target nominal GDP growth rate as $\left(\Delta y_{t}^{P}+\pi^{*}\right)$, the difference $\left(\Delta y_{t}+\pi_{t}\right)-\left(\Delta y_{t}^{P}+\pi^{*}\right)$ can be defined as the nominal GDP gap, or $N G D P_{t}^{\text {Gap }}$. Substituting gives

$$
i_{t}^{*}=i_{t}^{n}+N G D P_{t}^{\text {Gap }}
$$

The rule thus defined allows for a policy response to the current nominal GDP gap only. A better rule, allowing the policy response to depend on the accumulated gap, is

$$
i_{t}^{*}=i_{t}^{n}+N G D P_{t}^{G a p}+\lambda_{3}\left(\sum_{i=0}^{\infty} N G D P_{t-i}^{G a p}\right) .
$$

Equation (16) is our proposed nominal GDP rule. Although there is some debate over what the target NGDP growth rate should be, we follow Hatzius and Stehn (2011), Sumner (2011) and Woodford (2012) who call a NGDP growth rate target near 5 percent, the average nominal GDP growth rate over the course of the Great Moderation. ${ }^{14}$ The $N G D P_{t}^{\text {Gap }}$ is therefore calculated as the difference between the actual NGDP growth rate in the current period and 5 percent. The $\sum_{i=0}^{\infty} N G D P_{t-i}^{G a p}$ term is constructed by creating a NGDP trend based on the targeted NGDP growth rate. The percent difference between actual NGDP and this trend NGDP up through the last period is the accumulation of past misses and consequently equal to $\sum_{i=0}^{\infty} N G D P_{t-i}^{G a p}$. We base our trend of the Great Moderation period up through 2000 since that would be the time frame available to Federal Reserve officials prior to their use of naïve inflation targeting. ${ }^{15}$ As a robustness check, we also present an alternative estimate of the $\sum_{i=0}^{\infty} N G D P_{t-i}^{G a p}$ by taking the percent difference between the CBO's estimate of "potential" NGDP and actual NGDP. In setting the value for $\lambda_{3}$, we follow McCallum $(1988,1993)$ who implements a nominal GDP target that also corrects for past misses with a weight of $0.5 .^{16}$

To calculate the neutral nominal interest rate, $i_{t}^{n}$, we take our productivity-based neutral real estimate from earlier in the paper and add to it the expected inflation rate over the next year. ${ }^{17}$ Figure 11 shows how what this rule would have implied for the path of the federal funds rate during the productivity boom in the early 2000. Given the accelerating growth in nominal GDP at this time, the nominal GDP rule would have begun raising the federal funds rate target much sooner than what actually happened. The federal funds rate target would have 3.5 percent in mid-2003 and to about 6.5 percent by late 2004 . By this rule's standard, monetary policy was extremely loose in the 2002-2006 period.

\section{Conclusion}

Our findings suggest that, following the dot.com crash, the Fed, relying upon an expectations-augmented Phillips Curve framework rather than a neo-Wicksellian one, was tempted to treat rapid productivity growth as an opportunity to hold interest rates below their theoretically neutral levels without risking inflation. By responding this way, the Fed inadvertently fueled the subprime boom. To avoid contributing to the boom, the Fed should have allowed the

${ }^{14}$ Selgin (1997) argues that the targeted NGDP growth should vary based on the expected factor input growth.

${ }^{15}$ We specifically use the $1984-2000$ period.

16 Unlike our rule, McCallum uses the monetary base as the instrument of monetary policy.

17 We use the inflation forecasts from the Philadelphia Federal Reserve's Survey of Professional Forecasters. 
productivity surge to manifest itself in a heightened federal funds rate and a lower equilibrium rate of inflation.

Because it implicitly allows for a lowering of the target funds rate in response to productivity-growth based changes in the neutral rate, a conventional Taylor rule would have provided for a more neutral monetary response. The Fed could have achieved a still more neutral stance, however, had it adhered to a nominal GDP growth rate target, for unlike a conventional Taylor Rule such a target entirely avoids the tendency for excessive monetary accommodation of unusually rapid productivity growth. 


\section{References}

Ahrend, Rudiger, Boris Cournède and Robert Price. 2008. "Monetary policy, market excesses and financial turmoil." OECD Economics Department Working Paper No. 597.

Anderson, Richard G., and Kevin L. Kleisen. 2010. "FOMC Learning and Productivity Growth (1985-2003): A Reading of the Record." Federal Reserve Bank of St. Louis Review (March/April): 129-53.

Bernhardsen, Tom, and Karsten Gerdrup. 2007. “The Neutral Real Interest Rate.” Norges Bank Economic Bulletin 78 (2): 52-64.

Christiano, Lawrence, Roberto Motto, and Massimo Rostagno. 2007. "Two Reasons Why Money and Credit May be Useful in Monetary Policy." NBER Working Paper No. 13502 (October).

Edge, Rochelle M., Thomas Laubach, and John C. Williams. 2005. "Monetary Policy and Shifts in Long Run Productivity Growth." Unpublished (May 9).

Entekhabi, Niloufar. 2008 “ Technical Change, Wage and Price Dispersion, and the Optimal Rate of Inflation." Unpublished working paper (March).

Federal Reserve System, Board of Governors. Federal Open Market Committee Transcripts. At http://www.federalreserve.gov/monetarypolicy/fomc_historical.htm

Ferguson, Roger. 2004. “Equilibrium Real Interest Rate: Theory and Application.” Remarks delivered at the University of Connecticut School of Business, http://www.federalreserve.gov/boarddocs/speeches/2004/20041029/default.htm Chairman Ferguson, October 29.

Fernald, John. 2009. “A Quarterly, Utilization-Adjusted Series on Total Factor Productivity.” Unpublished manuscript, Federal Reserve Bank of San Francisco, August 16.

Frederick, Shane, George Loewenstein, and Ted O'Donoghue. 2002. "Time Discounting and Time Preference: A Critical Review." Journal of Economic Literature 40(2): 351-401.

Galí, Jordi. 1999. Technology, employment and the business cycle: Do technology shocks explain aggregate fluctuations. American Economic Review 89, 249-271.

Greenspan, Alan. 2004. Speech delivered at the Annual Meeting of the American Economic Association, San Diego, CA.

Gordon, Robert. 2010. "Revisiting U.S. Productivity Growth over the Past Century with a View of the Future." NBER Working Paper 15834.

Hatzius, Jan, and Sven Jari Stehn, “The Case for a Nominal GDP Level Target," Goldman Sachs US Economics Analyst no. 11/41, Oct. 14, 2011.

Hendrickson, Joshua. 2012. An Overhaul of Federal Reserve Doctrine: Nominal Income and the Great Moderation, Journal of Macroeconomics, Vol. 34, p. 304 - 317

Iacoviello, Matteo and Stefano Neri 2010. "Housing Market Spillovers: Evidence from an Estimated DSGE Model". American Economic Journal: Macroeconomics, 2, 125-64.

Laubach, Thomas, and John C. Williams. 2003. "Measuring the Natural Rate of Interest" Review of Economics and Statistics, 85, 1063-1070.

Lombardi, Marco, and Silvia Sgherri. 2007. "(Un)Naturally Low? Sequential Monte Carlo Tracking of the US Natural Interest Rate." ECB Working Paper 794.

McCallum, B.T., 1988. Robustness Properties of a Rule for Monetary Policy. Carnegie-Rochester Conference Series on Public Policy 29, Autumn, 173-203.

McCallum, B.T., 1993. Speci_cation and Analysis of a Monetary Policy Rule for Japan. Bank of Japan Monetary and Economic Studies, November, 1-45. 
Oliner, Stephen, Daniel Sichel, and Kevin Stiroh. 2007. "Explaining a Productive Decade." Brookings Papers on Economic Activity, 1:2007, 81-137.

Robson, Arthur J, and Larry Samuelson. 2007. "The Evolution of Time Preference with Aggregate Uncertainty." American Economic Review 99 (5) (December): 1925-1953.

Schmitt-Grohé, Stephanie, and Martin Uribe. 2009. “Optimum Inflation Stabilization in a Medium-Scale Macroeconomic Model.” In Klaus Schmidt-Hebel and Frederic S. Mishkin, eds., Monetary Policy under Inflation Targeting. Santiago, Chile: Central Bank of Chile, 125-186.

Selgin, George. 1997. "Less Than Zero: The Case for a Falling Price Level in a Growing Economy." London: Institute of Economic Affairs.

Sims, Eric. 2012. "Taylor Rules and Technology Shocks." Economic Letters.116, 92-95.

Sumner, Scott, "Re-Targeting the Fed," National Affairs, Fall 2011, pp. 79-96.

Sutherland, Donald. 2009. "Monetary Policy and Real Estate Bubbles." Working paper, Institute for SocioEconomic Studies, February 11.

Tambalotti, Andrea. 2003. “ Optimal Monetary Policy and Productivity Growth.” Unpublished manuscript, Princeton University, February 11.

Taylor, John. 2007. "Housing and Monetary Policy." In the Kansas City Federal Reserve Economic Policy Symposium, 463-476.

Taylor, John. 2009. Getting off Track, Stanford, California: Hoover Institution Press.

Weidener, Justin, and John C. Williams. 2009. "How Big is the Output Gap? "Federal Reserve Bank of San Francisco, Economic Letters 32, 3, 19, 1- 3.

Williams, John C. 2003. "The Natural Rate of Interest." Federal Reserve Bank of San Francisco Economic Letter 32 (October 31).

Whelan, Karl. 2009. "Technology Shocks and Hours Worked: Checking for Robust Conclusions." Journal of Macroeconomics, 31, 231-239.

Woodford, Michael. 2003. "Interest and Prices", Princeton University Press: Princeton.

Woodford, Michael. 2012. "Methods of Policy Accomodation at the Interest-Rate Zero Lower Bound”. In the Kansas City Federal Reserve Economic Policy Symposium, 185-288. 


\section{Appendix: Data Sources and Description}

Total factor productivity estimates are from Fernald (2009) while output gap estimates are from Laubach and Williams (2003). The federal funds rate, CPI, unemployment rate, and housing starts are from the St. Louis Fed's FRED Database at the St. Louis Federal Reserve Bank.

The neutral real federal funds rate is based on the equation, $r_{t}^{n}=\bar{r}^{n}+\left(g_{t}^{e}-\bar{g}\right)$, where $r_{t}^{n}$ is the current period neutral real interest rate, $\bar{r}^{n}$ is the long-run, steady neutral real interest rate, $g_{t}^{e}$ is the current expected year-on-year TFP growth rate, and $\bar{g}$ is the mean year-on-year TFP growth rate. We assume $\bar{r}^{n}=2$ percent and estimate $g_{t}^{e}$ using an exponential weighted moving average of past year-on-year TFP growth rates with a current period weight of 0.70 .

The time-varying Taylor equation estimates rely on quarterly data covering the period 1984:Q1 - 2007:Q4. The interest rate is the average annualized federal funds rate; inflation is measured by the percentage change of the CPI; and output gap estimates are from the Congressional Budget Office. The initial weights are normalized at 0.5. 
Figure 1

Total Factor Productivity Growth

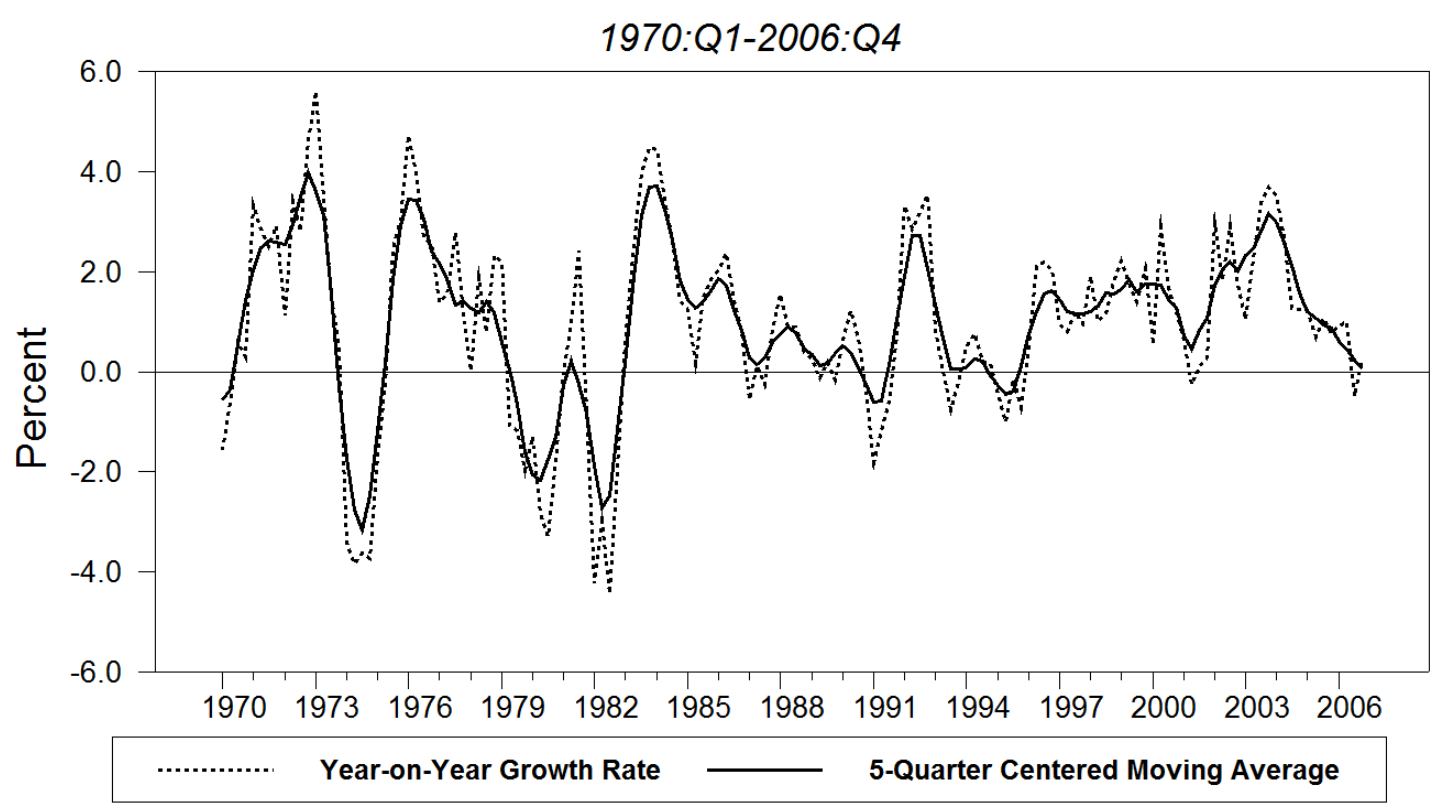

Source: Fernald (2009) and authors' calculations.

Figure 2

Approximate Neutral and Actual Real Federal Funds Rate

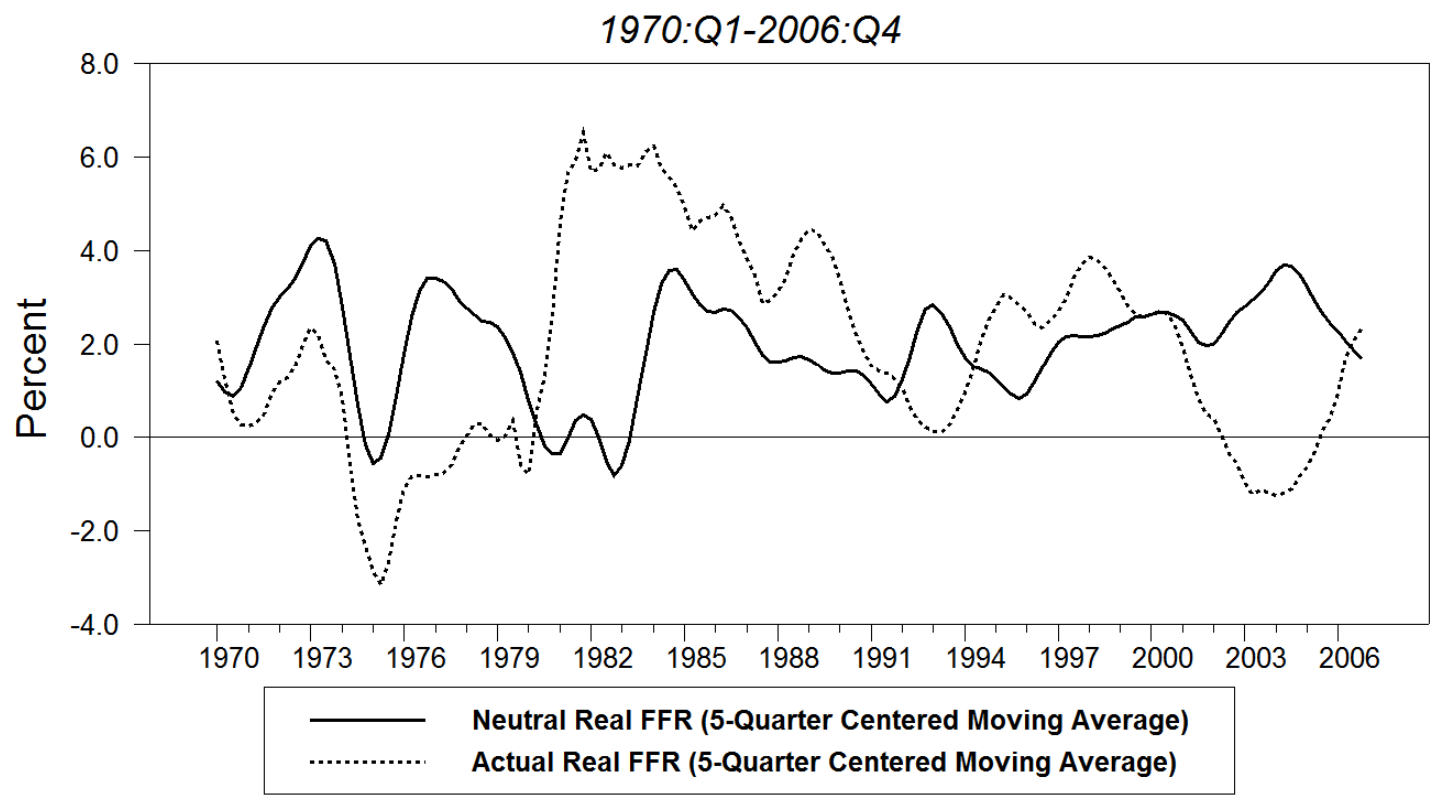

Source: Fernald (2009), Fred Databse, and authors' calculations. 


\section{Figure 3}

The Productivity Gap

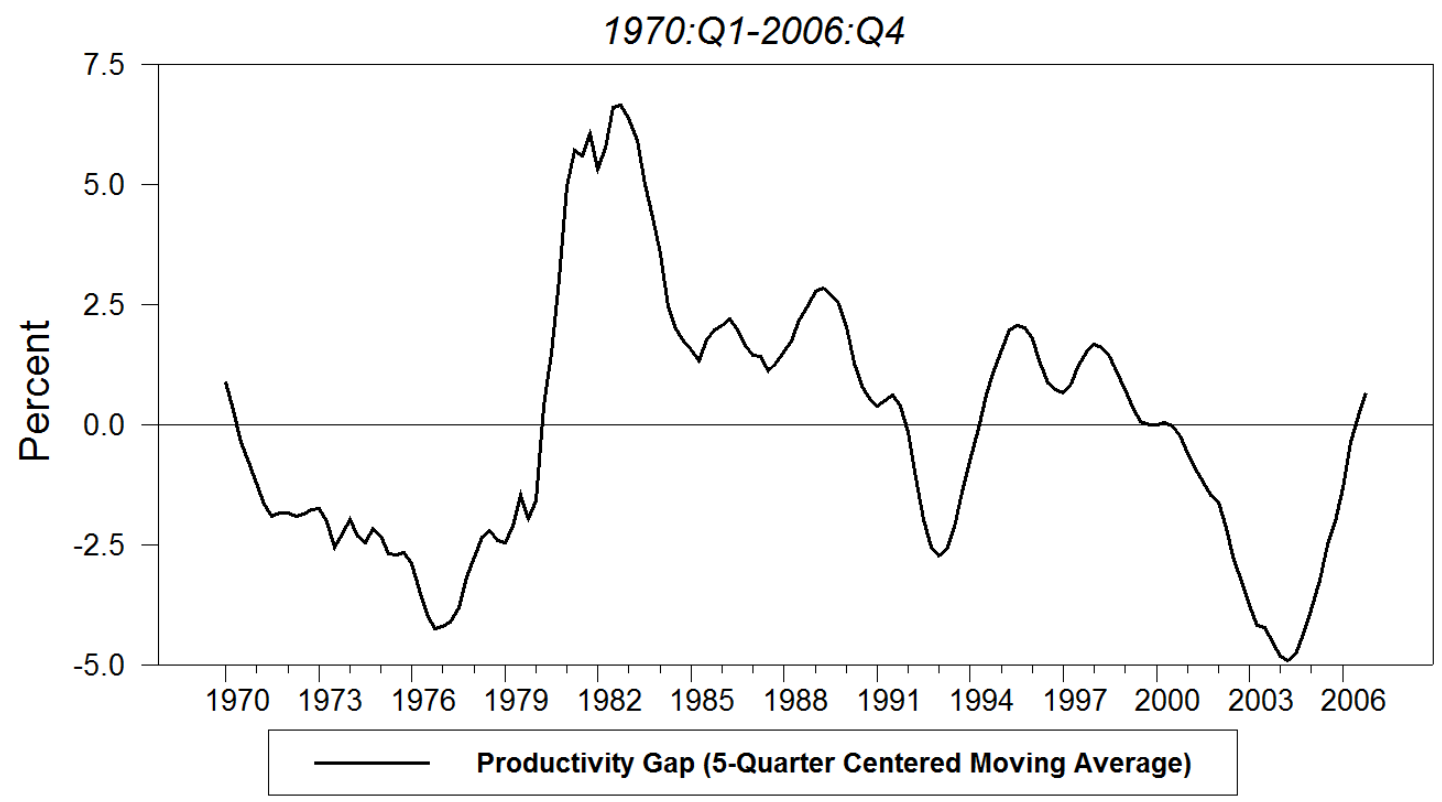

Source: Fernald (2009), Fred Databse, and authors' calculations.

\section{Figure 4}

\section{The Productivity and Output Gaps}

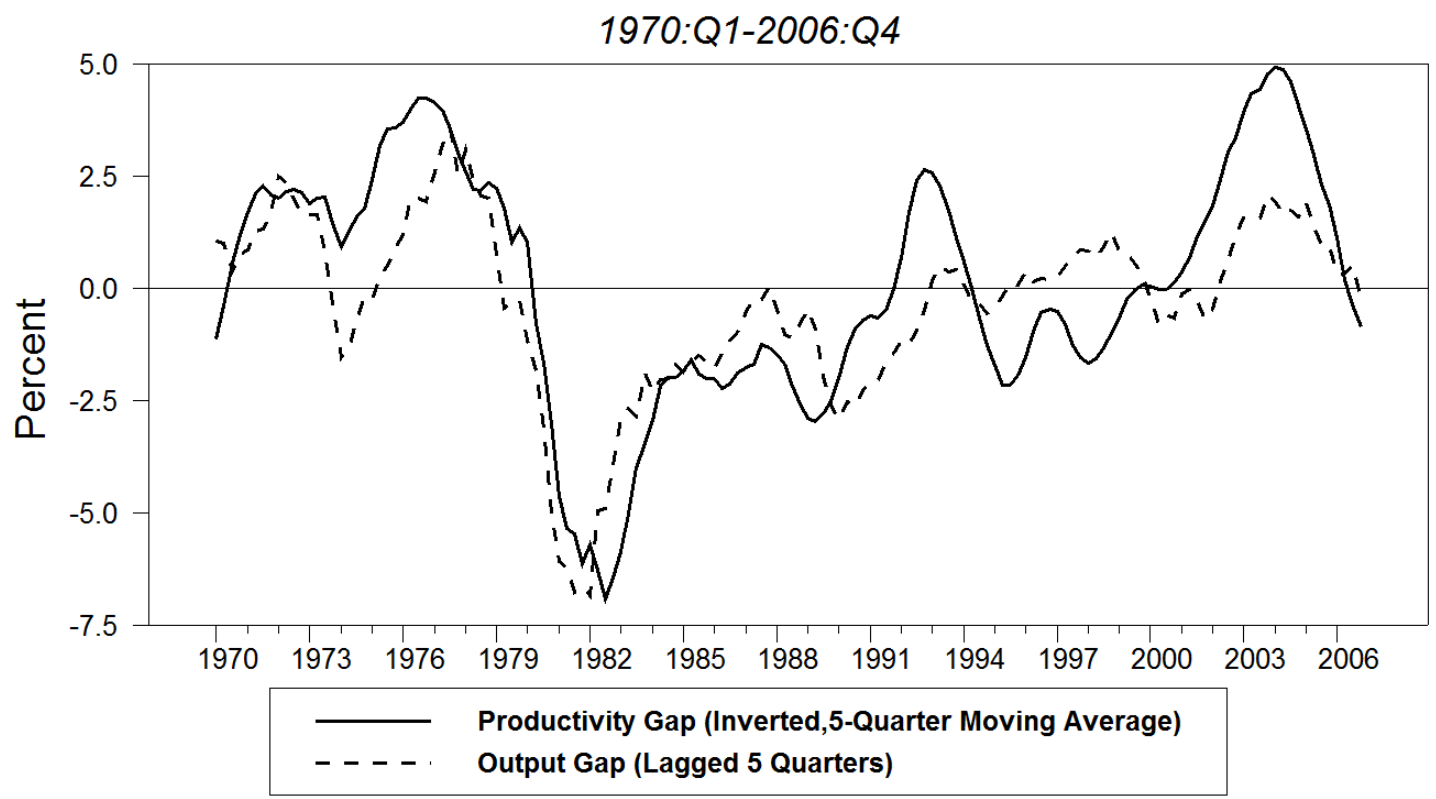

Source: Fernald (2009), Laubach and Williams (2003), Fred Databse, and authors' calculations. 
Figure 5

The Productivity Gap and Housing Starts

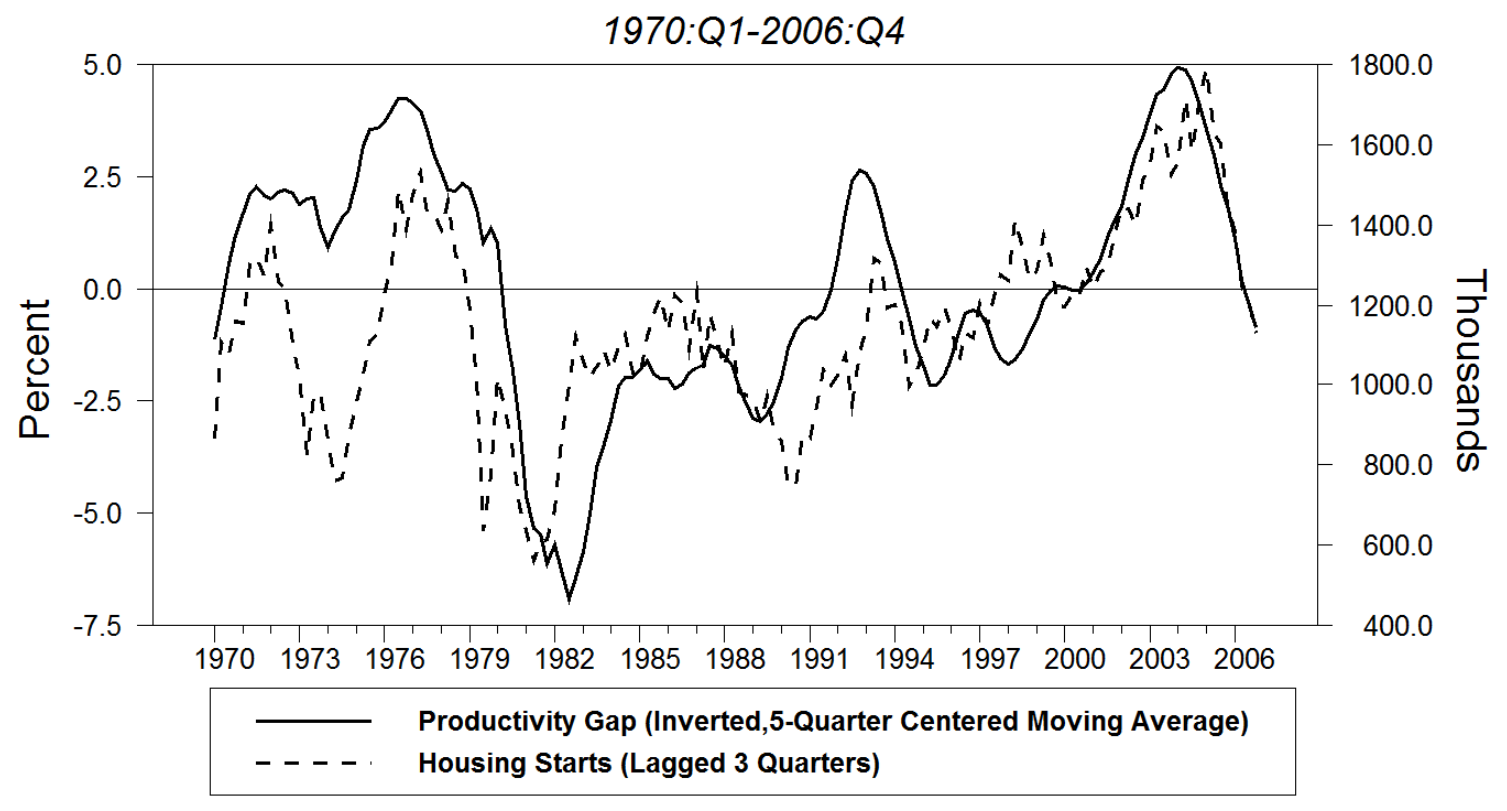

Source: Fernald (2009), Fred Databse, and authors' calculations. 
Figure 6

\section{Cumulative Response to Typical TFP Shock}
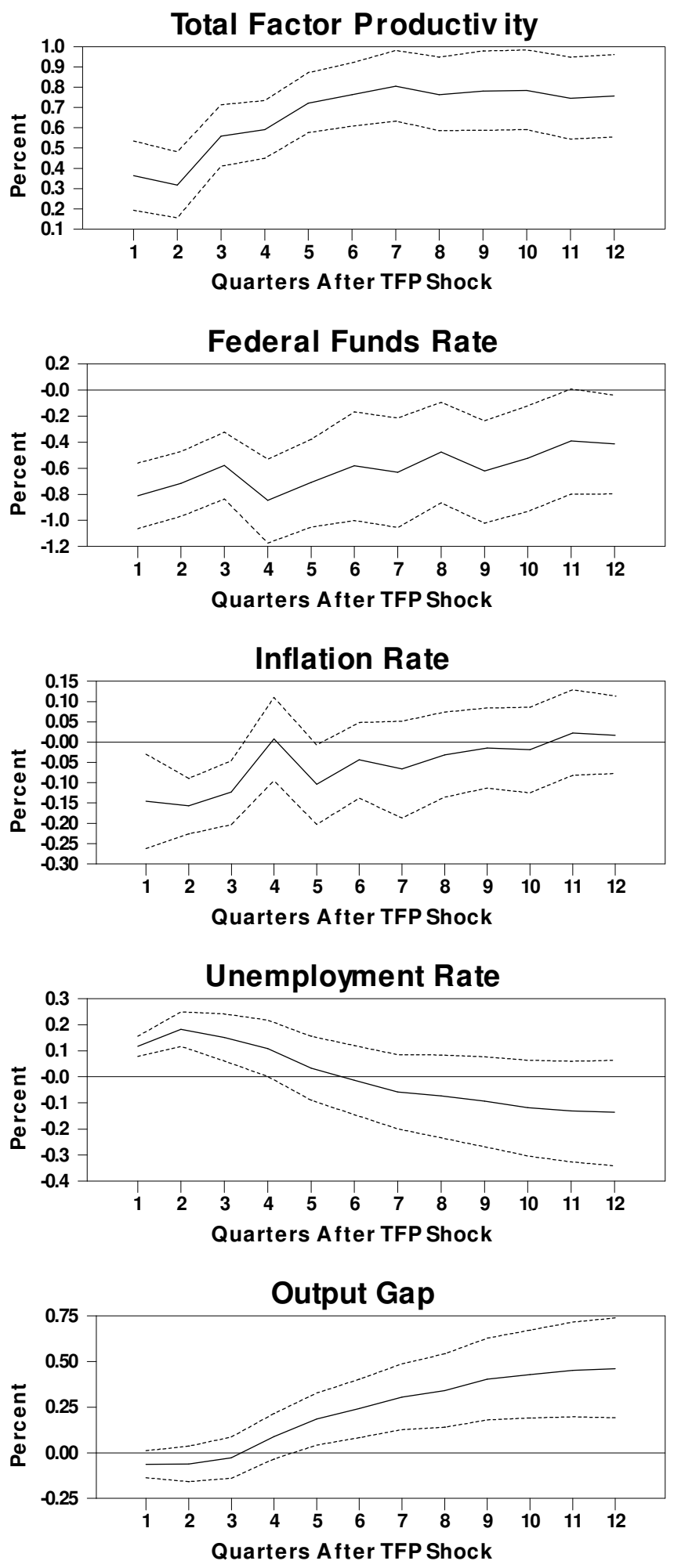
Figure 7

The Productivity and Taylor Rule Gaps

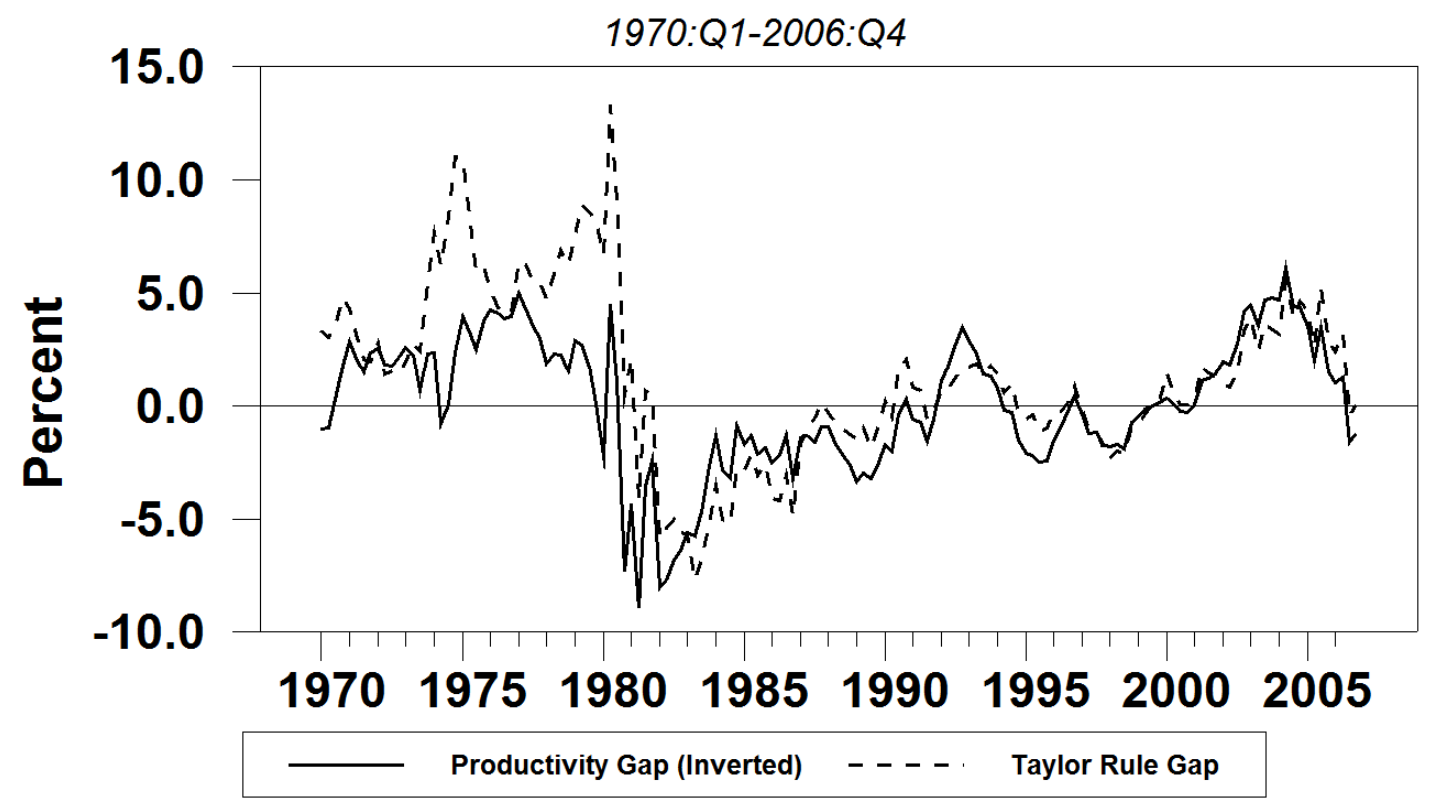

Source: Fernald (2009), Fred Databse, and authors' calculations.

Figure 8

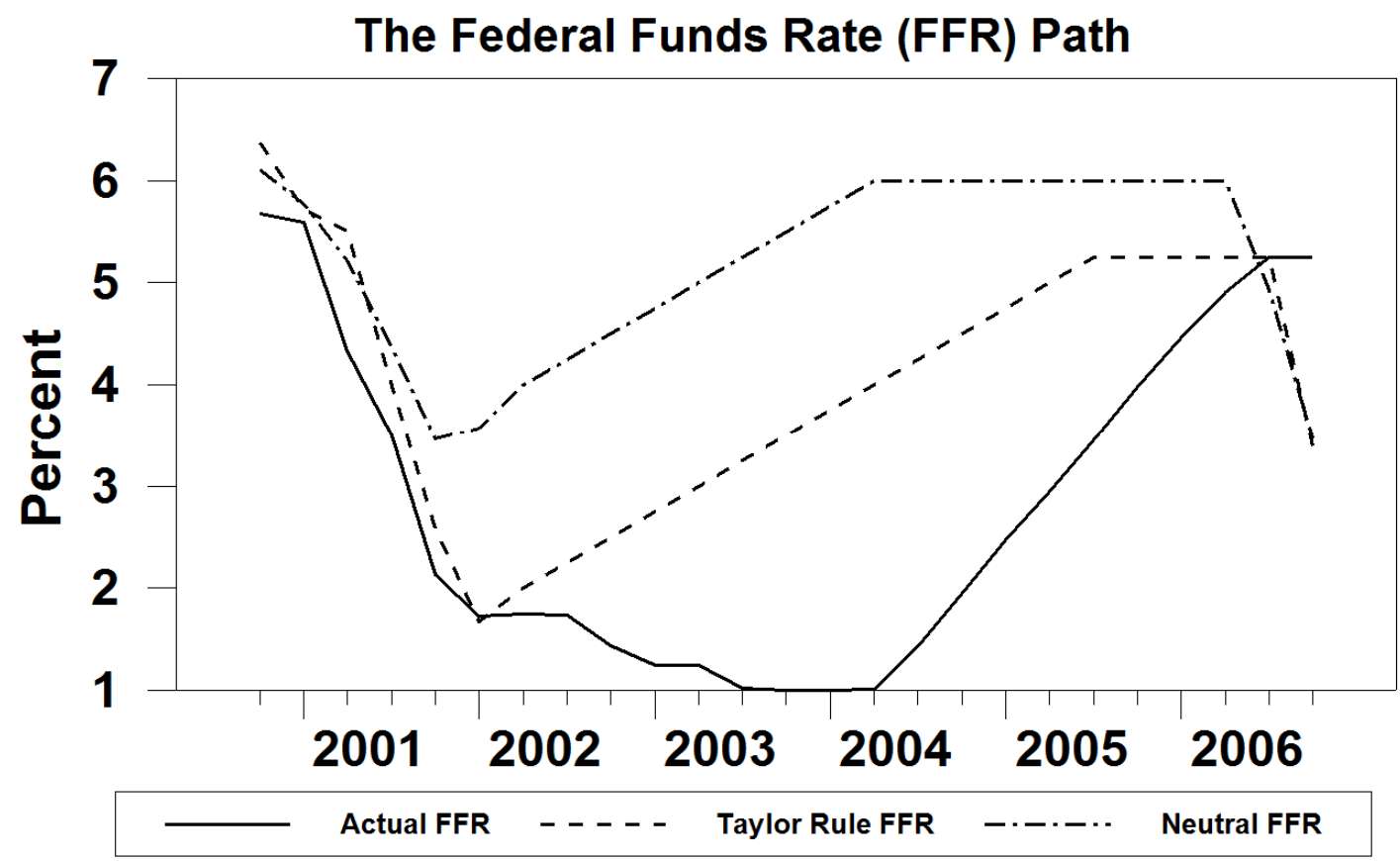

Source: Fred Databse and authors' calculations. 
Figure 9

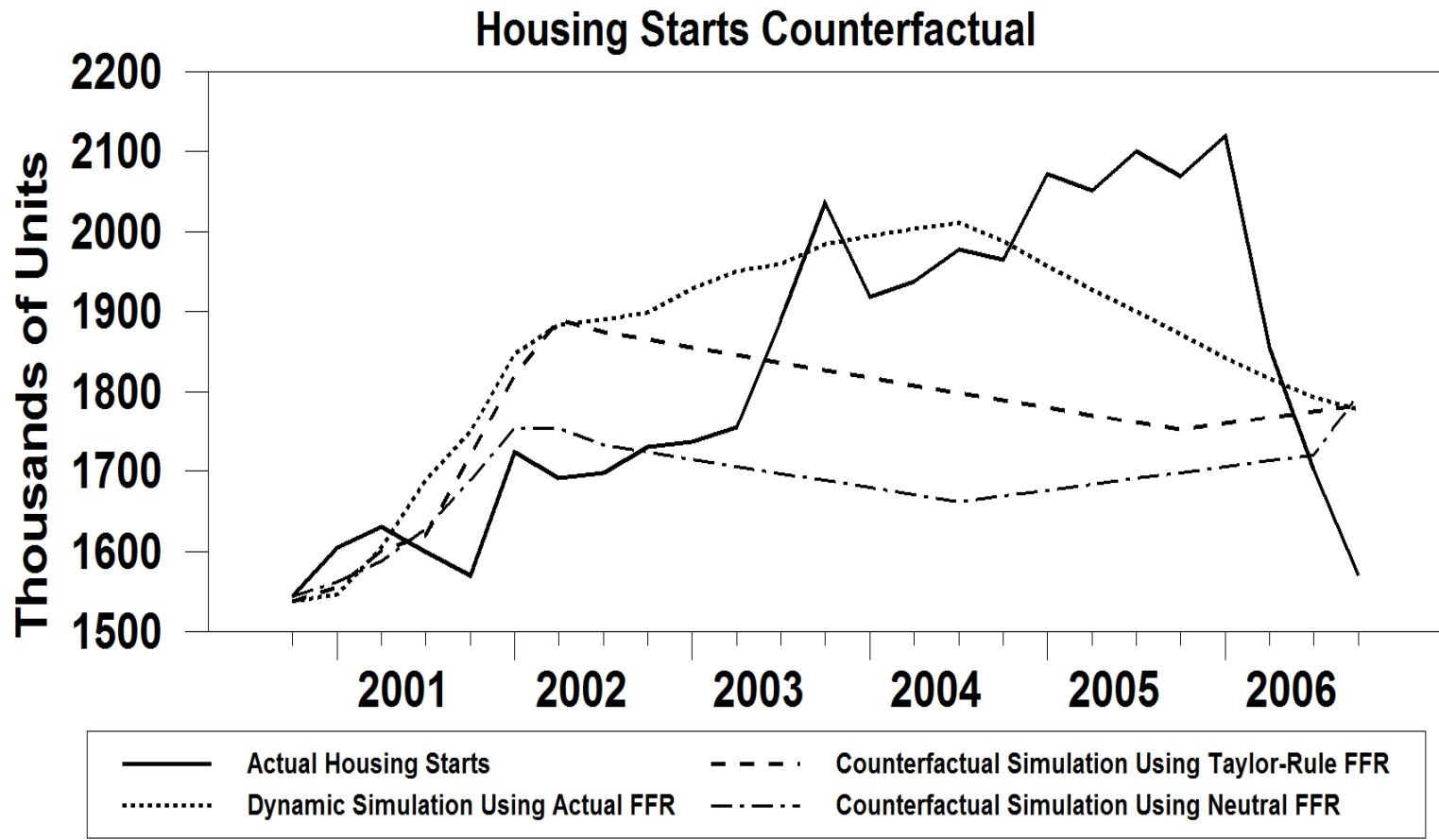

Source: Fred Databse and authors' calculations.

Figure 10

Time-Varying Taylor-Equation Coefficients \& Expected TFP Growth 1984:Q1-2007:Q4
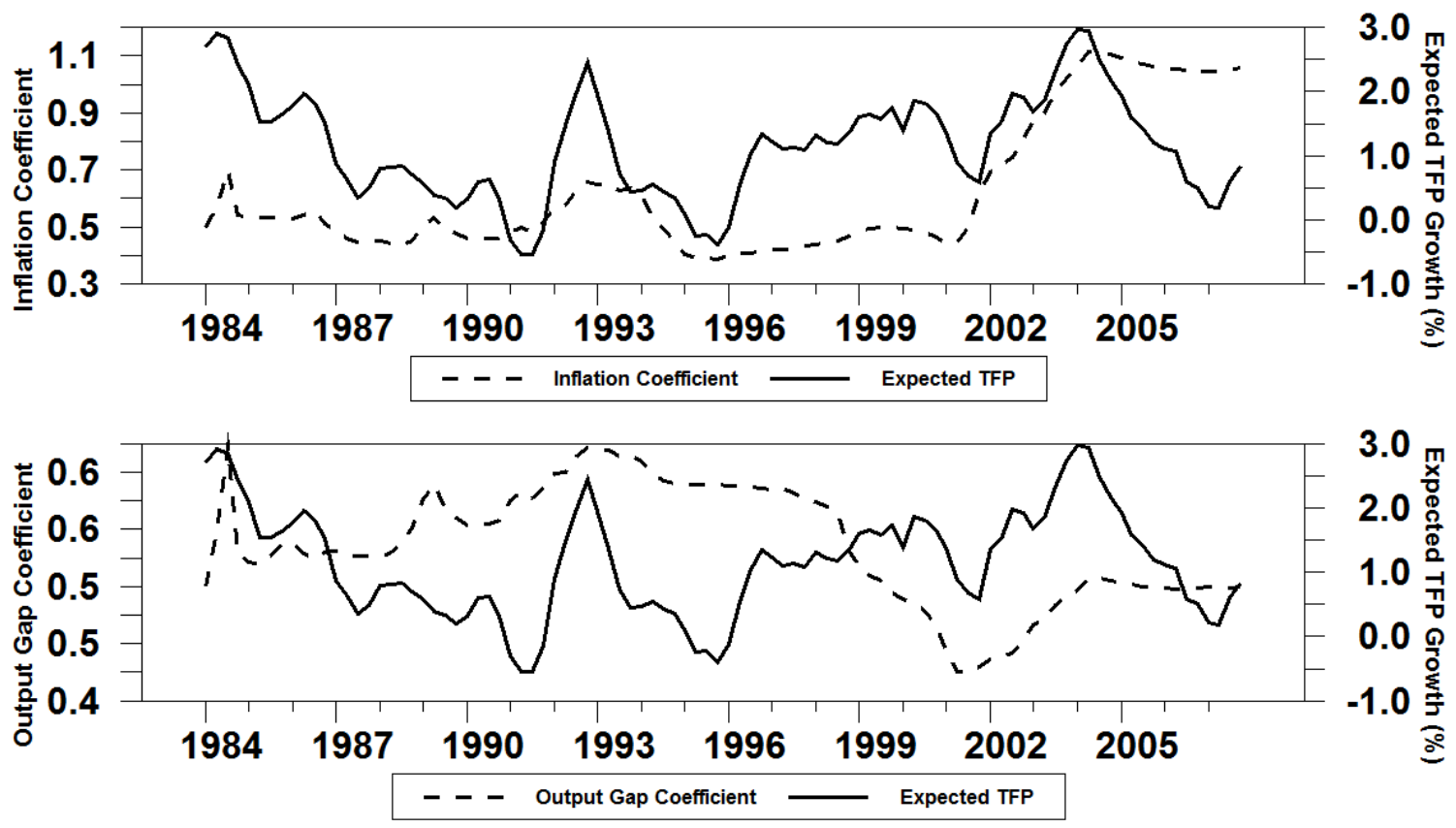

Source: Fred Databse and authors' calculations. 
Figure 11

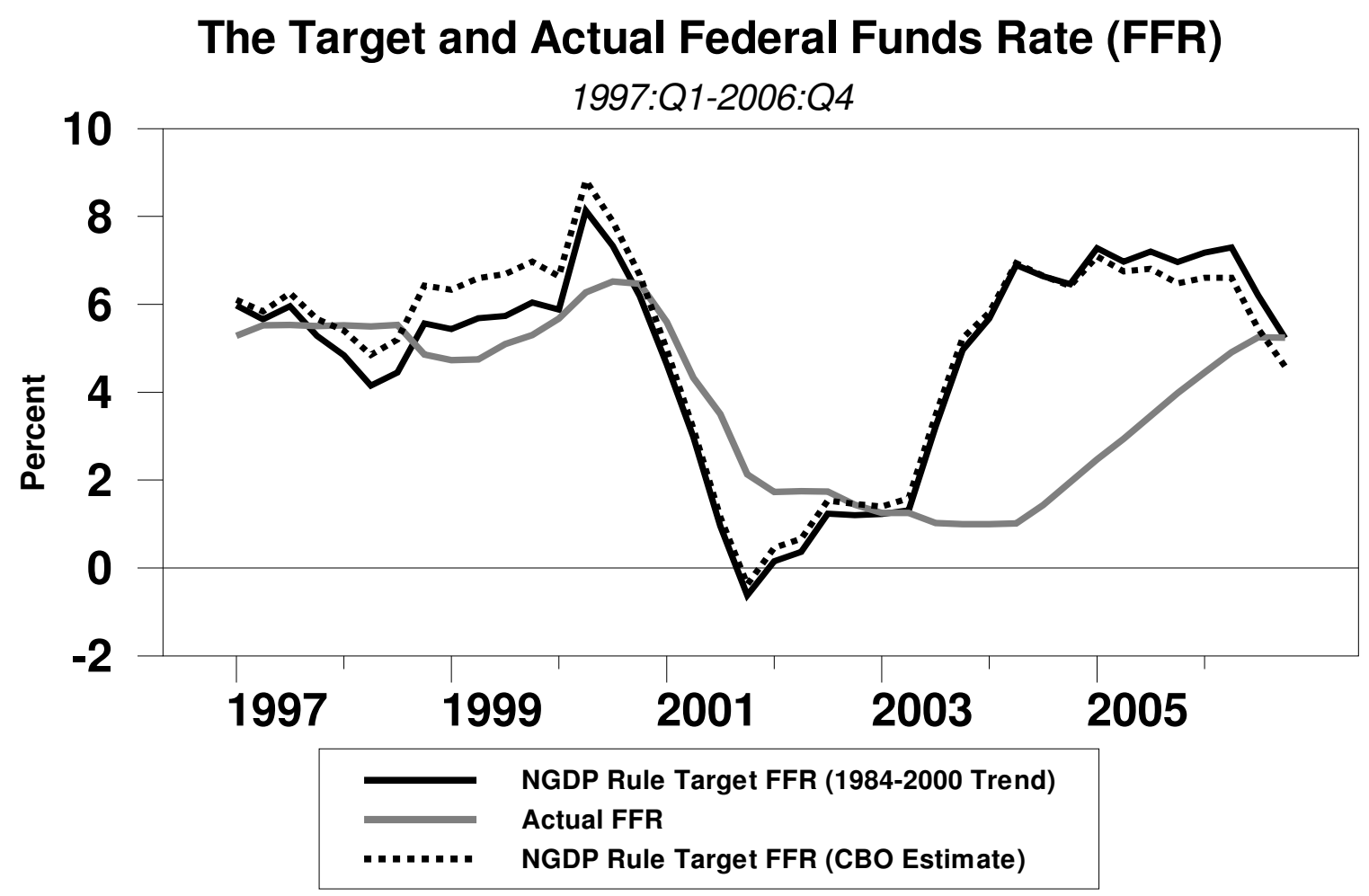

Source: Fred Databse and authors' calculations. 